\title{
Recognising the Role of the Emotion of Fear in Offences and Defences
}

\author{
Susan S M Edwards*
}

\begin{abstract}
Anger, its part in human conduct and in crime commission has been much discussed and accorded a privileged status within the law, whilst the role of fear has been less considered. Notwithstanding, fear and related emotional states have received some recognition as intrinsic elements of the perpetrator's object integral to the actus reus of certain offences and relevant to the defendant's mens rea of some defences. The harm caused by deliberately or negligently instilling fear in another is inconsistently considered in law as is its impact on criminal responsibility and mens rea. Fear has been recently acknowledged as a permissible cause of loss of self-control in a partial defence to murder. ${ }^{l}$ It remains a contested emotion and as with anger the male experience of what circumstances trigger fear predominates.
\end{abstract}

\section{Keywords Fear; Offences; Defences; Emotion; Coercion}

\section{Introduction}

This article considers the recognition of fear and related emotions in the construction of some offences and defences, exploring those offences where the perpetrator's aim is to create a state of fear, shock or alarm in another and those defences which recognise that fear may cause a person to commit a criminal offence. There is no consistent legal framework or doctrinal coherence within the law regarding this emotion. So, for example, whilst the perpetrator's motive, purpose, and intention in causing a state of fear in another is recognised within some statutory provisions and identified as an element of the offence, there are other offences, where fear and distress, whilst not explicated in the statutory provision, is nevertheless considered an integral component of the factual and evidential matrix. The Protection of Harassment Act (PHA) 1977, is a significant watershed providing specifically for "fear of violence" (s.4) and "stalking involving fear of violence or serious alarm or distress" (s. 4A), recognise these as harms to be regulated thus challenging the privileging of physical harm as the only assaultive wrongdoing. ${ }^{2}$ Significantly, $R v$ Ireland; $R v$ Burstow $^{3}$

\footnotetext{
*Professor of Law, University of Buckingham ; email:susan.edwards@buckingham.ac.uk

${ }^{1}$ Coroners and Justice Act 2009 s.55 (3).

2 J. Feinberg, The moral limits of the criminal law. Vol.1, Harm to Others (Oxford University Press, 1984).

${ }^{3} R v$ Ireland; $R v$ Burstow [1997] 4 All ER 225, "My Lords, it is easy to understand the terrifying effect of a campaign of telephone calls at night by a silent caller to a woman living on her own. It would be natural for the victim to regard the calls as menacing. What may heighten her fear is that she will not know what the caller may do next. The spectre of the caller
} 
established that fear occasioned by silent telephone calls made by a former partner could amount to "psychiatric injury"4 amounting to bodily harm for the purposes of the Offences Against the Person Act (OAPA)1861. Horder ${ }^{5}$ noted in 1998:

"It is odd that fear remains comparatively under-analysed by criminal lawyers, as a possible species of harm, as compared with bodily and psychiatric injury (of great concern both to criminal and civil lawyers) or with 'moral offence' (of great concern to liberal political thinkers). As a species of harm, fear has a relatively transitory character inconsistent with its recognition as a kind of 'bodily' harm for the purposes of the Offences against the Person Act 1861."

With regard to causation the law is not ready however to concede a causal link between the harm and fear occasioned by the perpetrator's domestic abuse and the victim's suicide. ${ }^{6}$ Although the trial judge in Dhaliwal said, "where 'a decision to commit suicide has been triggered by a physical assault which represents the culmination of a course of abusive conduct,' it would be possible for the Crown 'to argue that that final assault played a significant part in causing the victim's death". ${ }^{7}$ In $R v B W^{8}$ (Wallace) the original trial was terminated in order for the Court of Appeal to consider the prosecution challenge on two evidential rulings pursuant to s. 58 Criminal Justice Act 2003. In this case Berlinah Wallace had thrown sulphuric acid on her partner who sustained such horrific and life limiting injuries that he sought euthanasia in Belgium and as a Belgium national was permitted to do so. The question for the court was whether Wallace had in effect caused his death and if so could she be charged with murder and/or manslaughter. The Court of Appeal ruled that the cause of the deceased's injuries was sufficient to be 'a' cause, if not 'the' cause, of his death and ordered a retrial on a charge of murder such that the matter of causation could be put before a jury. At retrial, however the jury acquitted her of murder and manslaughter. ${ }^{9}$ Storey ${ }^{10}$ commenting on the Court of Appeal's ruling, "it should be noted that its precedent value may be limited. As Sharp LJ put it, the case was 'tragic and unusual' (at [7]), involving 'very special and particular facts' (at [59] and also at [76])".

arriving at her doorstep bent on inflicting personal violence on her may come to dominate her thinking. After all, as a matter of common sense, what else would she be terrified about? The victim may suffer psychiatric illness such as anxiety neurosis or acute depression" per Lord Steyn at 228.

${ }^{4}$ J. Horder, "Reconsidering psychic assault" [1998] Crim. L. R. 392.

${ }^{5}$ J. Horder, "Reconsidering psychic assault" [1998] Crim. L. R. 392.

${ }^{6}$ See $R v$ Dhaliwal [2006] EWCA Crim 1139, “...the wife had committed suicide following the husband's abuse of her, the prosecution case depended on the submission that psychological injury without any recognised psychiatric illness was capable of constituting 'bodily harm' within the meaning of ss 18,20 and 47 of the 1861 Act. The judge ruled that there was no basis upon which a reasonable jury, properly directed, could convict the defendant of either manslaughter or unlawful wounding." The prosecution applied for leave to appeal against the judge's ruling under s 58 of the Criminal Justice Act 2003 and the Court of Appeal confirmed the trial judge's ruling. See also D. Ormerod, "Suicide resulting from prolonged abuse -abuse causing psychological harm but not recognised psychiatric illness or Condition" [2006] Crim.L.R. 923. J.Horder and L. McGowan, "Manslaughter by Causing Another's suicide" [2006] Crim. L.R. 1035. "R v Dhaliwal" Commentary: M. Burton Judgment: V. Munro and S. Shah in Feminist Judgments From Theory to Practice R. Hunter, C. McGlynn, E. Rackley (2010 Hart).V. E.Munro and R. Aitken, "Adding Insult to Injury? The Criminal Law's Response to Domestic Abuse - Related Suicide in England and Wales" [2018] Crim. L.R 732-741. See also Susan S.M.Edwards in "A Socio-Legal Evaluation of Gender Ideologies in Domestic Violence Assault and Spousal Homicides" Victimology: An International Journal, Vol 10, 1985 no 1-4 186,187,nb 4, Policing London No. 13 Jul/Aug 1984 LSPU Police Monitoring and Research Group, who writes "Krishna Sharma found hanging in her own home may have been killed by her husband. Although the coroner's verdict was one of suicide Krishna had for many years been subjected to her husband's violence....the police had been approached on numerous occasions including the night before her death when they had advised her to contact a Citizen's Advice Bureau...". See also Sharma case cited in Southall Black Sisters, Homebreakers to Jailbreakers (Zed Press, 2003).

${ }^{7} R v$ Dhaliwal [2006] EWCA Crim 1139.

${ }^{8} R v B W[2018]$ EWCA Crim 690.

${ }^{9}$ See https://www.itv.com/news/2018-05-22/judge-to-hear-legal-submissions-ahead-of-acid-attack-sentencing/

${ }^{10}$ T. Storey, "Court of Appeal: Voluntary Acts and the Chain of Causation in Homicide Cases: The Need for 'Free and Unfettered Volition"” $R v$ Wallace [2018] EWCA Crim 690, JCL 82 (292) 293, 2018. 
The fear and distress intentionally inflicted on victims by perpetrators in the context of posting offensive online communications on social media platforms is further recognised by the law in creating new and developing existing offences. Police and prosecutors have developed more robust guidelines ${ }^{11}$ and the Law Commission has recently published a scoping report on the problem ${ }^{12}$ recognising fear as one of the psychological harms inflicted. ${ }^{13}$ The Serious Crime Act (SCA) 2015 s.76, also extends an understanding of other harms by criminalising "coercive conduct" (albeit limited to the context of an intimate or family relationship) giving recognition to the characteristics and tactics of domestic violence which typically involve controlling and placing the victim in a state of alarm, distress and fear. ${ }^{14}$

Within the framework of criminal defences the Coroners and Justice Act (CandJA) 2009 establishes "fear of serious violence" s.55 (3) as a "trigger" (s.55 (2)) for "loss of self-control" /manslaughter, provided the fear is of serious violence from the victim (s. 55 (3)). Immediate fear characterised by surprise, shock, "startlement" 15 and alarm, or being in fear characterised by a chronic state of apprehension, anticipation, foreboding and heightened anxiety, ${ }^{16}$ are both recognised. Significantly the Court of Appeal in Challe ${ }^{17}$ recognised coercive conduct as contributing to the mens rea of the appellant, in quashing a wife's conviction for murder, taking into account fresh evidence of coercion and control by the deceased husband (discussed below). ${ }^{18}$ Whilst not explicitly set out within the statute fear and analogous emotional states are also recognised as possible causes for self-defensive action both in pleas of self-defence ${ }^{19}$ and within the "householder defence." ${ }^{20}$ Fear and similar emotional states are also relevant to the factual basis of the defences of duress, necessity, omission, and "compulsion" (Modern Slavery Act (MSA) 2015 s. 45).

Significantly the impact of fear and similar states is also acknowledged in the enhanced provisions for vulnerable witnesses and those with mental disabilities. Witnesses in fear of participating in the criminal process or otherwise vulnerable are accommodated in the provision of witness anonymity, ${ }^{21}$ admissibility of witness statements in place of oral evidence ${ }^{22}$ and special measures to

\footnotetext{
${ }^{11}$ Social Media - Guidelines on prosecuting cases involving communications sent via social media

Revised: 21 August 2018, https://www.cps.gov.uk/legal-guidance/social-media-guidelines-prosecuting-cases-involvingommunications-sent-social-media

${ }^{12}$ Law Commission Scoping Report on Abusive and Offensive Online Communications, 1 November 2018. https://www.lawcom.gov.uk/abusive-and-offensive-online-communications/

13 Law Commission Scoping Report on Abusive and Offensive Online Communications, 1 November 2018. https://www.lawcom.gov.uk/abusive-and-offensive-online-communications/At para 3.33 p.52.

${ }^{14}$ D. H. Funkenstein, “The Physiology of Fear and Anger” Scientific American Vol. 192, No. 5 (1955), pp. $74-$

81. P. Brett, "The physiology of provocation" [1970] Crim. L.R. 634.

${ }^{15} \mathrm{~N}$. Wake uses this term in her article "Battered women, startled householders and psychological self-defence: Anglo-Australian perspectives" JCL 77(5) 2013 pp. 433-457.

${ }^{16}$ K. Dunlap, "Are emotions teleological constructs” American Journal of Psychology xlix 1932.

17 See The Times March $1^{\text {st }} 2019$ p. 7.

${ }^{18}$ See also appeal against sentence Regina v Georgina Sarah Anne Louise Challen [2012] 2 Cr. App. R. (S.) 20 reducing the 22 years to 18 years. V. Bettinson, "Aligning partial defences to murder with the offence of coercive or controlling behaviour" Journal of Criminal Law 2019.

${ }^{19}$ Criminal Law Act 1967 s. 3. See also Palmer v R [1971] A.C. 814 approved in $R v$ McInnes 55 Cr. App. R. 551.

${ }^{20}$ Criminal Justice and Immigration Act 2008 s.76 (6), "The degree of force used by D is not to be regarded as having been reasonable in the circumstances as $\mathrm{D}$ believed them to be if it was disproportionate in those circumstances." Section 76(5A) of the Criminal Justice and Immigration Act 2008, as amended by s.43(2) Crime and Courts Act 2013 which inserts "grossly" to read "grossly disproportionate".

${ }^{21}$ Witness anonymity is provided for in an "anonymity order" Coroners and Justice Act 2009 ss.86-90, where the court must have regard to any "reasonable" fear (a) that the witness or another person would suffer death or injury, or (b) that there would be serious damage to property, s. 88 (6).

${ }^{22}$ See Criminal Justice Act 2003 s.116 (2) (e) and (3) which allows for admissibility of hearsay where the witness is in fear. Section 46 of the Youth Justice and Criminal Evidence Act 1999, is applicable to an adult witness whose evidence would be diminished by fear or distress (see R. v Horncastle; R. v Marquis; R. v Carter [2010] 2 A.C. 373).
} 
facilitate the giving of evidence ${ }^{23}$ including pre-recorded cross-examination. ${ }^{24}$ The Criminal Justice and Public Order Act 1994 s. 51 (2) (a) recognises the fear and harm caused by witness intimidation. ${ }^{25}$ In the context of domestic violence "no drop" policies have been developed with the intended aim of recognising a victim's fear of reprisal such that the provisions of the Criminal Justice Act (CJA) 2003 s.116(2)(e) permit the admissibility of a written statement in place of oral evidence. Fear may also be taken into account when considering reporting restrictions. ${ }^{26}$ The emotion of fear and analogous emotional states is also recognised at the sentencing stage ${ }^{27}$ and in victim impact statements. For example burglary, ${ }^{28}$ robbery ${ }^{29}$ and domestic violence ${ }^{30}$ are just three categories of criminal cases where the psychological impact on the victim is frequently severe causing fear and other psychological harm. Where a defendant fearing violence kills then that is also a mitigating factor when considering sentence length in murder (Schedule 21, Criminal Justice Act 2003) and in determination of minimum term in relation to a mandatory life sentence s.269 (5).

\section{Understanding emotional states}

\footnotetext{
${ }^{23}$ Coroners and Justice Act 2009 s.17 identifies witnesses who are eligible for assistance on grounds of fear or distress at the prospect of testifying.

${ }^{24}$ See also s.28 Youth Justice and Criminal Evidence Act 1999 and Pre Recording of ABE interviews. See also E. Henderson, "Theoretically Speaking; English Judges and Advocates Discuss the Changing Theory of Cross-Examination" [2015] Crim. L. R. pp. 929-948. See also presentation delivered by HHJ Plaschkes QC to the Criminal Bar Association on $5^{\text {th }}$ May 2018 "Ground Rules Hearing and Pre-Recorded Cross Examination." See also presentation delivered by HHJ Everett "Section 28 - progress to date" at St Mary's Centre Manchester 16 ${ }^{\text {th }}$ Annual Conference 2018, "Rape: Not as isolated issue: Sexual Violence and Multiple types of abuse" $25^{\text {th }}-26^{\text {th }}$ April,

${ }^{25}$ See $R v$ Hudson, $R v$ Taylor [1971] 2 Q.B. 202.

${ }^{26}$ Youth Justice and Criminal Evidence Act 1999, ss.44, 45, 45A provides for [44] - Restrictions on reporting alleged offences involving persons under 18 if quality of testimony might be compromised by fear of reporting. Reporting restrictions, Section 46 of the YJCEA 1999, applicable to an adult witness whose evidence would be diminished by fear or distress.

${ }^{27}$ Fear is also an aggravating factor relevant to culpability considered at the sentencing stage across a range of offences i.e., "causing another to fear violence" may provide grounds for a "behaviour order" if considered necessary to protect a person from such conduct (Criminal Procedure Rules 2015 (S.I. 2015 no. 1490), pt. 31). The Protection from Harassment Act 1997, s.5 (2) (b) "restraining orders" recognise the need to prevent conduct which may cause another to fear violence. See also Sentencing Guidelines Council guidance https://www.sentencingcouncil.org.uk/wp-content/uploads/Intimidatory-OffencesGuideline_WEB.pdf Intimidatory Offences definitive guideline,2018 since where fear and distress is caused culpability is higher i.e. Protection from Harassment Act 1997 (s. 2A) (s. 2) (s. 4) (s. 4A), Crime and Disorder Act 1998 (s. 32 (1)(a)(b)), Criminal Justice and Courts Act 2015 (s. 33), Serious Crime Act 2015 (s.76), Offences against the Person Act 1861 (s. 16). ${ }^{28}$ See $R v$ Griffin (Martin) $R v$ Bennett (Gavin Mark) [2018] EWCA Crim 2538; $R$ v Nichols (Simon Keith) [2018] EWCA Crim 134: $R v$ Clarke (Morgan) R. $v$ Andrews (Declan) $R v$ Thompson (Anton Craig) [2018] EWCA Crim 185.

${ }^{29} R$ v Hussain (Karim), $R$. v Alexander (Mickelle) [2018] EWCA Crim 2550; $R$ v Makin (Kieron Anthony) [2017] EWCA Crim 2615, note victim impact " 3 Being attacked in that way in that lonely spot had a serious psychological impact on the victim. She had long-standing stress and anxiety and had to take some time off work. She still felt the physical effects of the attack 9 months later and was finding it difficult to sleep. She feared going out by herself, especially at night, and was prescribed medication". $R$ v Steven Arthurs [2018] EWCA Crim 882, "Miss Shamaoon's victim personal statement reveals, unsurprisingly, just what a severe impact the robbery has had upon her and her children. At the time of making the statement they were afraid to go out unaccompanied, they were no longer safe in their own home, and her daughter was receiving medical treatment in the hope of mitigating the long term psychological impact of the robbery". $R v$ Jeffrey (Rory William) R. v Caroll (Matthew Bryan) [2018] EWCA Crim 2135; “[7] The effect on Miss Chadwick was considerable. In her Victim Personal Statement, dated 6 January 2018, she explained that she had never been so afraid in her whole life and could not get the image of the man who had robbed her out of her head. The robbery had, she said, changed her life. She was anxious all the time, could not sleep, would get into a panic and had been signed off work for seven weeks".

${ }^{30} R v$ Roe (Andrew) [2018] EWCA Crim 1584; the victim no longer went out and she felt constantly scared.R. $v$ DH [2017] EWCA Crim 2503.The victim impact statement indicated that she had been terrified in her own home and was worried about the effect of the attack on the children.
} 
Understanding emotional states (including fear) derives from perspectives of medicine, biologism, psychiatry, ${ }^{31}$ psychology, and to a lesser extent philosophy ${ }^{32}$ and social constructionism. ${ }^{33}$ From the medical perspective emotions are instincts, drives and impulses, reflexive expressions of inner pathological states over which the individual has little control. Such understandings are material to law's construction of mens rea and responsibility for action, defences and mitigation. ${ }^{34}$ Medical and biological theorisations of emotional behaviour have dominated the legal narrative. So, for example, within homicide defences, an essentialist or pathological construction of anger as explosive, reflexive and uncontrollable, shaped the law on provocation informing its immediacy requirement (at least until s. 54 (2) CandJA). ${ }^{35}$ Fact finders looked for proof of loss of self-control in recognised, typified, reflexive and automative expressions of anger evidenced in police statements by defendants' linguistic descriptions of "boiling over," "seeing red" and "snapping" 36 . With regard to fear the medical and biological model is concerned with its impact on the brain and the parasympathetic system and the effect on the psychological state and cognitive function and behaviour, such that experiencing fear or living in or with fear may result in an impaired or total lack of capacity, prompt self-defensive action, or result in inaction or failure to act. Emotional responses are not however hermetically sealed. The Royal College of Psychiatrists in their response to the Law Commission's Consultation paper on "Partial Defences to Murder" stated that the emotion of fear and anger are not distinct. ${ }^{37}$

Pertinent to a consideration of understanding the emotions of fear and anger and their expression are the observations of social constructionists ${ }^{38}$ who explore the role of cultural and historic context in shaping the expression of emotion and the fashioning of the signs ${ }^{39}$ language ${ }^{40}$ and "speech acts," ${ }^{41}$ which articulate emotion and may afford legitimate and understandable excuses ${ }^{42}$ for behaviour. Expressions of emotion may also be "performative," 43 intended as statements, functioning as symbolic theatrical demonstrations ${ }^{44}$ For example, Sarah Thornton ${ }^{45}$ sharpened the knife, so she said in her police statement, and then killed Malcolm Thornton. This was interpreted by the prosecution as a preparatory act evidencing intention and by the defence as an elaborate dramaturgical ${ }^{46}$ gesture. In the context of anger, Horder explores the cultural and gendered contiguity of anger's accepted triggers. ${ }^{47}$ It

\footnotetext{
${ }^{31}$ J. Bourke, Fear: A cultural History, (Virago, 2005).

32 P. Fisher, The Vehement Passions, (Princeton University Press, 2002). J. Bourke, Fear: A cultural History (Virago, 2005).

${ }^{33}$ G. Fisher, and Kyum Koo Chon, "Durkheim and the Social Construction of Emotions" Social Psychological Quarterly, vol. 52, no. 11989 pp. 1-9. G. Bendelow, S.J. Williams, (eds), Emotions in Social Life: Critical Themes and Contemporary Issues, (Routledge, 1997).

${ }^{34}$ Insanity pleas and diminished responsibility (CJA 2009 s. 52) rely on pathological constructions of states of mind. See Law Commission Discussion Paper, Criminal Liability: Insanity and Automatism, (Law Com. TSO, 2013).

35 Devlin J., in $R$ v Duffy [1949] 1 All ER 932. Coroners and Justice Act 2009 s. 54 (2) now allows for a delay without negating a loss of self-control manslaughter defence.

${ }^{36}$ Susan S.M. Edwards, "Anger and Fear as Justifiable Preludes for Loss of Self-Control” (2010) 74 JCL 223-241, 233.

${ }^{37}$ Law Commission Report, Partial Defences to Murder No 290 (Law Com. TSO, 2004) para 3.99, p. 53.

${ }^{38}$ E. Doyle McCarthy, "The Social Construction of Emotions: New Directions from Culture Theory" in Social Perspectives on Emotion Vol. 2 (1994 JAI Press) p. 268. M. Douglas, Rules and Meanings, (Penguin, 1974). R. Harré, (ed) The Social Construction of Emotions (Oxford and New York, Basil Blackwell, 1988).

${ }^{39}$ F. de Saussure, Course in General Linguistics see http://home.wlu.edu/ levys/courses/anth252f2006/saussure.pdf

${ }^{40}$ J. Austin, Philosophical Papers (Clarendon Paperbacks, 1962).

A. Schutz, The Phenomenology of the Social World (Heinemann, 1974), J. Culler, On Deconstruction: Theory and Criticism After Structuralism (Cornell, 2007). J. Searle, Expression and Meaning: Studies in the Theory of Speech Acts (Cambridge University Press, 1979). See P. N. Stearns and C. Z. Stearns, "Emotionology: Clarifying the History of Emotions and Emotional Standards" The American Historical Review Vol. 90, No. 4 (1985), pp. 813-836.

${ }^{41}$ J. Austin, Philosophical Papers (Clarendon Press, 1962). H. Geertz, (1959) The Vocabulary of Emotion https://doi.org/10.1080/00332747.1959.11023175

${ }^{42}$ A. Schutz, The Phenomenology of the Social World (Heinemann, 1974).

E. Doyle McCarthy, "The Social Construction of Emotions: New Directions from Culture Theory" in Social Perspectives on Emotion, Vol. 2 (1994 JAI Press) p. 268.

${ }^{43}$ J. Austin, Philosophical Papers (Clarendon Press, 1962).

${ }^{44}$ A. Read, Theatre and Law (Macmillan, 2015).

${ }^{45} R v$ Thornton [1996] 1 W.L.R. 1174.

${ }^{46}$ As derived from I. Goffman, The Presentation of Self in Everyday Life (Penguin, 1959). See also A. Read, Theatre and Law (Macmillan, 2015).

${ }^{47}$ J. Horder, Provocation and Responsibility (Clarendon Press, Oxford) 26.
} 
is significant that the law has recently yielded to challenges to the pathological model such that within a loss of self-control defence an angered lethal response once legitimated upon a finding of a partner's sexual infidelity in provocation, is now expressly excluded in statute ${ }^{48}$ demonstrating, in this instance, the receptiveness of law to changing norms and impliedly law's recognition that the emotion of anger is not wholly reducible to pathology.

\section{The Offences -Perpetrators Intending or Causing a State of Fear}

Within the framework of criminal offences is recognised different degrees of harm and suffering inflicted by the perpetrator in causing fear, anxiety, distress or apprehension. The very act of instilling fear in another is recognised as part of the modus operandi and actus reus in offences of violence and threats of physical violence, ${ }^{49}$ bullying, and harassment related conduct and most recently coercion and compulsion. Causing or bringing about a state of fear is found explicitly twinned with specific index offences, for example as an element of the offence of robbery (Theft Act 1968, s.8 (1)) i.e. using force on any person "or puts or seeks to put any person in fear of being then and there subjected to force". There are other offences where whilst fear and distress is absent from the probative elements required by statute, such emotions are nonetheless highly relevant to context and the factual narrative. For example, in Barot, ${ }^{50}$ a case involving terrorist acts and conspiracy to murder, the trial judge said, " $\mathrm{Th}[\mathrm{e}]$ project was, on its face, designed to achieve a number of further and collateral objectives, such as to cause injury, fear, terror and chaos. The expert evidence is that the project, if carried through, would have been unlikely of itself to cause death as opposed to causing considerable fear, panic and social disruption." In Haggarty, ${ }^{51}$ where the defendant was convicted of five counts of murder and four counts of terrorism, it was the statute regulating possession of an imitation firearm that caught the "harm" of causing fear. ${ }^{52}$

\section{Social Media offences}

In addition, there are other offences, for example, public order, harassment, and social media related ${ }^{53}$ ("cyber bullying," 54 sexually explicit images initially intended for private use "revenge porn" 55 , "trolling" inflammatory messages and "virtual mobbing" derogatory comments about another) where intending or causing similar and analogous states of (i) alarm or distress, ${ }^{56}$ (ii) serious alarm or

\footnotetext{
${ }^{48}$ Coroners and Justice Act 2009 s.55 (6) (c) the fact that a thing done or said constituted sexual infidelity is to be disregarded.

${ }^{49}$ However causing fear is surprisingly not mentioned in any of the terrorism statutes - Terrorism Act 2000, Anti-Terrorism Crime and Security Act 2001, Prevention of Terrorism Act 2005, Terrorism Act 2006, Counter Terrorism and Security Act 2015 or in the definition of terrorism, Terrorism Act 2000 s 1.,or s. 40 interpretation.

${ }^{50} R v$ Barot [2007] EWCA Crim 1119.

${ }^{51} R$ v Haggarty [2018] NICC 1.

${ }^{52}$ Possession of an imitation firearm with intent to cause fear of violence, contrary to art 17A of the Firearms (Northern Ireland) Order 1981.

53 See House of Lords "Social media and criminal offences" Communications Committee https://publications.parliament.uk/pa/ld201415/ldselect/ldcomuni/37/3704.htm . See also the proposal that "joint enterprise" might be applicable where a group organise the "virtual mobbing" of another. $R v$ Coleman (Daniel Andrew) [2013] EWCA Crim 1183. $R v$ Cordle (John William) [2016] EWCA Crim 1793. $R v$ Stockton (Shaun Thomas James) [2014] EWCA Crim 1188. $R v$ Riley (Anthony), [2017] EWCA Crim 243. $R v$ Casbolt (James Michael [2016] EWCA Crim 1377. $R v$ Bradburn (Ashley), Rv ACR v Bostan (Aamar) [2018] EWCA Crim 494.

${ }^{54}$ The Protection from Harassment Act 1997 s. 4, provides for the prosecution of cyber bullying where a person is put in fear of violence. (Recent amendments in s. 4A (1) (b) (i), (ii) includes stalking where "fear of violence" is caused, and a separate offence of stalking which causes "serious alarm or distress". See also Living in fear-the police and CPS response to harassment and stalking, a joint inspection by HMIC and HMCPSI critical of the failure to understand the persistent risks and dangers of this repeat behaviour, with the result that few perpetrators have been charged.

55 Criminal Justice and Courts Act 2015 s. 33 (1) (a) (b). See also Report on Violence against Women and Girls, which reported in the period 2015 to 2016 that only 206 prosecutions commenced. See S. Pegg, "A Matter of Privacy or Abuse? Revenge Porn in the Law" Crim. L.R. [2018] 512-530.

${ }^{56}$ Criminal Justice and Courts Act 2015 s.33 (1) (b) criminalises the disclosure of private photographs which cause distress.
} 
distress ${ }^{57}$ (iii) distress ${ }^{58}$ and (iv) distress or anxiety ${ }^{59}$ are recognised as statutory elements of the offence. The Malicious Communications Act (MCA) $1988 \mathrm{s.} 1^{60}$ criminalises sending letters etc. causing anxiety, and the Criminal Justice and Courts Act (CJCA) 2015 s.33 (1) (b) criminalises the disclosure of private photographs which cause distress. A lower threshold of "annoyance, inconvenience or needless anxiety" is provided for in the Communications Act (CA) 2003 s.127, where a "grossly offensive or of an indecent, obscene or menacing character" is sent or posted. Increasingly, the use of social media is part of a wider campaign of inflicting fear and terror in the intended victim. The fear Matthew Falder ${ }^{61}$ instilled in his victims through social media abuse is well known. The posting of offensive online communication is also an integral aspect of a campaign of violence against an intimate or former partner. Consider for example, the circumstances and context of the following cases. In $R v$ Coleman (Daniel Andrew) ${ }^{62}$ the victim had refused a relationship with the defendant, he then opened a false Facebook account in the name of the American serial killer, Ted Bundy, and said, "I should let you know I'm going to kill you and your housemates soon, especially the whore." In $R v$ Cordle (John William) ${ }^{63}$ the appellant, was charged under (PHA 1997 s.4) he sent texts threatening acid attacks, "I'd like to see Tanya's face after the acid is put on her face. ... God help you and your family". In $R v$ Stockton (Shaun Thomas James) ${ }^{64}$ the appellant, sent messages threatening to kill NB and "put her ten feet under." "Revenge porn" is also part of the perpetrators campaign. In $R v$ Riley (Anthony) ${ }^{65}$ following a knife attack, the complainant told the applicant that she no longer wanted a relationship with him. He tried to contact her by telephone and then posted videos on Facebook of them engaging in sexual activity. In $R v$ Casbolt (James Michael) ${ }^{66}$ the husband, sent a text to his former wife saying that he would post explicit images on Facebook. The service providers removed the images however, the appellant kept re-posting them sending the images to email contacts and to a publisher of pornographic magazines. In $R v$ Bradburn (Ashley) ${ }^{67}$ the appellant, (also charged with offences of rape, violence and other sexual offences) created and used a false Facebook profile to send unsolicited messages to five women and young girls in which he requested intimate photographs. In $R v A C^{68}$ the appellant, sent the victim hundreds of texts and emails of a sexual nature containing threats of sexual and physical violence. $R v$ Bostan (Aamar) $^{69}$ demonstrates the urgent need for guidance for judges in sentencing in these matters. ${ }^{70}$ Here, the Court of Appeal reduced the sentence of four months to two months imprisonment due to the limited disclosure and the nature of the images.

\footnotetext{
${ }^{57}$ Crime and Disorder Act 1998, s.32 (1) b.

${ }^{58}$ Criminal Justice and Courts Act 2015 s. 33. Disclosure of private photographs.

${ }^{59}$ Malicious Communications Act 1988 s.1 (b) criminalises sending letters etc., causing anxiety, and the lower threshold of

"annoyance, inconvenience or needless anxiety" is provided for in the Communications Act (CA) 2003 s.127, where a

"grossly offensive or of an indecent, obscene or menacing character" communication is sent or posted.

${ }^{60}$ Section 1 of the Malicious Communications Act 1988 (offence of sending letters etc. with intent to cause distress or anxiety), for subsection (4) substitute- - "(4) A person guilty of an offence under this section is liable-(a) on conviction on indictment to imprisonment for a term not exceeding two years or a fine (or both);(b) on summary conviction to imprisonment for a term not exceeding 12 months or a fine (or both).

${ }^{61}$ http://www.bbc.co.uk/news/uk-england-43114471; https://www.theguardian.com/technology/2018/feb/19/dark-webpaedophile-matthew-falder-jailed-for-32-years He contacted many individuals who later became his victims. There were 147 charges against him and after an international operation lasting several years he was eventually tracked down, prosecuted and convicted. He persuaded his victims to send him photographs he then blackmailed them with demanding more degrading images.

${ }^{62} R$ v Coleman (Daniel Andrew) [2013] EWCA Crim 1183.

${ }^{63}$ [2016] EWCA Crim 1793.

${ }^{64}$ [2014] EWCA Crim 1188.

${ }^{65} R v$ Anthony Riley [2017] EWCA Crim 243.

${ }^{66}$ [2016] EWCA Crim 1377.

${ }^{67}$ [2017] EWCA Crim 1399 Attorney General's Reference under Section 36 of the Criminal Justice Act 1988.

68 [2017] EWCA Crim 1452.

${ }^{69}$ See for example $R v$ Bostan (Amar) [2018] EWCA Crim 494. "The appellant sent the photo to the complainant's mother in October as an act of revenge because the complainant had made contact with his new girlfriend. Four months sentence was reduced to two months consecutive to the sentence imposed on 26 October 2017, was substituted.

${ }^{70}$ See CPS guidance https://www.cps.gov.uk/legal-guidance/social-media-guidelines-prosecuting-cases-involvingcommunications-sent-social-media

See also Communication network offences (Revised Communications Act 2003, ss. 127(1) and 127(2) Triable only summarily- Maximum: Unlimited fine and/or 6 months.
} 
Victims of social media harm have felt powerless given their limited legal redress. In $J P H v$ $X Y Z$ and others,${ }^{71} \mathrm{XYZ}$ sent a series of communications to JPH threatening to post private personal and compromising images on social media and/or to cause them to be published in magazines. XYZ's motive was revenge as JPH had brought their relationship to an end. An interim non-disclosure order (Human Rights Act 1998 s.12 (2) (b)) was applied for, since although the images had not been distributed friends of the alleged perpetrators had been instructed to distribute them should the police become involved. In Re J (a child) (contra mundum injunction) $)^{72}$ the High Court granted an injunction in family proceedings where the father had used social media to post offensive communication. Recent successful actions include the case of the 14 year old minor in Northern Ireland who settled out of court damages arising from Facebook postings. ${ }^{73}$ Chrissy Chambers ${ }^{74}$ sued her former partner for harassment, breach of confidence and misuse of private information.$^{75} \mathrm{He}$ had uploaded six films to a profile on a pornographic website "Redtube.com" without her knowledge some containing her name and her age. ${ }^{76}$ Causing anxiety, fear, distress and suffering in the victim is the intention of the perpetrator.

\section{Controlling and Coercive Conduct}

The recent inclusion of the offence of controlling and coercive conduct in an intimate or family relationship (SCA s.76 (1)) recognises causing "fear of violence" (76) (4) (a) or conduct having a "serious effect" (s.76 (4) (b) the latter requiring corroborative evidence of psychological or psychiatric harm. ${ }^{77}$ As the Court of Appeal in $R v$ Robert Joseph James Conlon ${ }^{78}$ explained "[26] The new offence targets psychological abuse in which one partner to a relationship coerces or controls the life of the other without necessarily or frequently using threats or violence. It follows, in our judgment that the manifestations of the serious effect on the victim of such behaviour by the offender will vary from case to case. In some cases, of which this was clearly one, the victim will, on occasions, find it difficult to resist the persuasive influence of the offender and may as a result convince herself that she is the one at fault". It is to be noted however that this offence is not being proceeded with on its own but when it forms part of a wider pattern of abuse including physical violence and rape where other charges are on the indictment. ${ }^{79}$

It is to be noted that the Domestic Abuse Consultation Response notes that up to March 2018, 9,053 offences of coercion recorded by the police and prosecutions for 960 offences were commenced

\footnotetext{
${ }^{71}$ [2015] EWHC 2871.

${ }^{72}$ See also Re J (a child) (contra mundum injunction) [2013] EWHC 2694 (Fam), [2013] All ER (D) 45 (Sep)

BFLS 1A[100]; CHM 11[1]; Rayden Noter up [T4.15] involving material uploaded by the father to "You Tube"

Where the family were involved in care proceedings.

${ }^{73}$ Damages: Facebook settled out of court. Northern Ireland case 14 year old minor see http://www.bbc.co.uk/news/uknorthern-ireland-42627373

${ }^{74}$ See "You Tube" - Chrissy Chambers case https://www.theguardian.com/technology/2018/jan/17/youtube-star-chrissy-

chambers-wins-damages-in-landmark-uk-revenge-porn-case

${ }^{75} \mathrm{See}$ https://www.theguardian.com/technology/2018/jan/17/youtube-star-chrissy-chambers-wins-damages-in-landmark-ukrevenge-porn-case

${ }^{76}$ See http://metro.co.uk/2018/01/17/youtuber-chrissy-chambers-awarded-damages-landmark-revenge-porncase-7237315/?ito=cbshare

Twitter: https://twitter.com/MetroUK | Facebook: https://www.facebook.com/MetroUK/

77 Susan S.M.Edwards, "Coercion and compulsion - re-imagining crimes and defences" [2016] Crim. L. R. 876-899. See also that fear in its various forms as examples of coercion is recognised in the Statutory Guidance Framework Controlling or Coercive Behaviour in an Intimate or Family Relationship, December 2015. https://www.gov.uk/government/publications/statutory-guidance-framework-controlling-or-coercivebehaviour-in-an-intimate-or-family-relationship

78 [2017] EWCA Crim 2450.

79 See $R$ v Parkin (Andrew) [2018] EWCA Crim 2764, the D would telephone her persistently, behaviour which intensified after their separation in August 2017. If C was absent from the family home when the offender arrived he would ask other members of the family where she was and would use the house telephone to call her, demanding to know where she was and what she was doing (count 4). See also $R v$ Rhyan Alexander Thomas [2018] EWCA Crim 2634, $R$ v JB [2018] EWCA Crim 2014, $R$ v Jordan Michelle Worth [2018] EWCA Crim 1923.
} 
at magistrates' courts. The Office for National Statistics (ONS) record (year ending December 2017) a total of 468 defendants prosecuted for coercive and controlling behaviour, resulting in eight cautions, 235 offenders convicted and 223 offenders sentenced for this offence. However, this offence is more likely to be proceeded with when it forms part of a wider pattern of abuse including physical violence and rape. ONS records coercive and controlling behaviour as the principal offence in $51 \%$ of all such prosecutions (468 cases).

Bettinson, notes the wider prosecutorial obstacle, "Unfortunately, criminal law frameworks struggle to capture the real nature of this harm. Instead the focus is on isolated physical injuries that can be seen where context is disregarded." ${ }^{\prime 0}$ Coercion is an integral aspect of cases before the family and criminal courts. Consider these following examples. Madhav Sharma and Jenny Seagrove divorced in 1988, Judge Clive Callman was reported as saying of Sharma, “...he set about vicariously to fulfil his personal need for success, standing and recognition, not only as the husband but the controller and dominator of the professional and personal life of a talented and rising star ... he helped his wife professionally until he began to interfere excessively and unreasonably with her professional life ... He knew her emotional weaknesses and exploited them. To fulfil his own needs he sapped Miss Seagrove's self-confidence and self-esteem through undue criticism and reduced her systematically to a state of complete emotional dependence." " The iconic photograph of Charles Saatchi grabbing Nigella Lawson by the neck in a restaurant in London in 2013 was conduct reported to have been explained by him during court proceedings in these words, "I was not gripping, strangling or throttling her. I was holding her head by the neck to make her focus, can we be clear?....... a "playful tiff'". ${ }^{82}$

In $R v$ Ahluwahlia ${ }^{83}$ the defendant in a written note to her husband, submitted in evidence, revealed her abject subornation to him.

"Deepak, if you come back I promise you - I won't touch black coffee again, I won't go to town every week, I won't eat green chilli, I'm ready to leave Chandikah and all my friends, I won't go near Der Goodie Mohan's house again, even I am not going to attend Bully's wedding, I eat too much or all the time so I can get fat, I won't laugh if you don't like, I won't dye my hair even, I don't go to my neighbour's house, I won't ask you for any help."

Significantly the CPS published a troubleshooting guide for police and CPS in Dec 2017 and an aide memoire for use in cases of controlling and coercive behaviour. ${ }^{84}$ Evidence of coercion is a factor influencing CPS decision to continue with a prosecution. The CPS in its most recent guidance asserts "Prosecutors should ensure they are familiar with the Government definition of domestic abuse and the impacts and dynamics of how abuse may be perpetrated... There is no specific statutory offence of domestic violence and/ or abuse-it is a general term describing a range of controlling and coercive behaviours ..."

Non-fatal strangulation is also a typical method of abuse used to coerce, control and frighten. In Newman $(2007)^{85}$ the appellant was convicted of attempted murder, (BCE) was adduced from a number of previous girlfriends of previous strangulation. In Stubley (Anthony Colin) (2017) ${ }^{86}$ against a

\footnotetext{
${ }^{80}$ V. Bettinson, "Criminalising Coercive Control in Domestic Violence Cases: Should Scotland Follow the Path of England and Wales?" [2016] Crim. L. R. 165-180.

${ }^{81}$ Cited in Susan S. M,Edwards "Coercion and compulsion - re-imagining crimes and defences" Crim. L.R. 2016, 12, 876-899.

${ }^{82}$ Cited in Susan S.M. Edwards "The strangulation of female partners" Crim. L.R. 2015, 12, 949-966.

${ }^{83} R$ v Ahluwalia [1992] 4 All ER 889.

${ }^{84}$ See https://www.cps.gov.uk/legal-guidance/controlling-or-coercive-behaviour-intimate-or-family-relationship

${ }^{85}$ Regina v Foster Practice Note, Regina v Newman, Regina v Kempster, Regina v Birmingham [2007] EWCA Crim 2869, [2008] 1 W.L.R. 1615.

${ }^{86}$ [2016] EWCA Crim 2304.
} 
background of sexual assault, domestic violence included attempted strangulation. All of these conduct create a state of fear.Certainly as I have argued elsewhere more needs to be done to recognise this highly dangerous form of abuse which can result on death. ${ }^{87}$

\section{Culpability/Fault}

With regard to culpability/fault the law recognises several levels (intention, recklessness, knowledge, and negligence). Intention is the requisite mens rea in threats to kill where the offence is to cause another to fear violence. ${ }^{88}$ (There is a distinction, though not articulated here, between creating in the victim a mere apprehension or contemplation of fear and causing the victim to fear something specific which may be identified). A lower level of culpability is indicated in the language of "necessary intent or awareness" found in the PHA (s.4) ${ }^{89}$ where, the offence is made out if a person, whose course of conduct amounting to stalking, causes another to fear on at least two occasions that violence will be used. ${ }^{90}$ "Awareness" is also the standard of culpability required with regard to some public order offences. ${ }^{91}$ Whilst "knows" or especially "ought to have known"92 (applicable in the crime of coercion in an intimate or familial relationship (SCA s.76 (1) (d)) introduces an even lower level of culpability and an objective element where even if the defendant was unaware that his conduct would have the stated effect (SCA 2015 s. 76 (4)) s/he may be liable. ${ }^{93}$

These several offences establish beyond doubt the law's concern and purpose in criminalising the behaviour of causing in another mental/physical harm of fear and similar emotional states. ${ }^{94}$ Notwithstanding the above, the project of recognising the harm of causing fear by whatever means is wanting and identifying the wider ambit of what needs to be done is outside the scope here. However a plea for the criminalising of non-fatal strangulation (nfs) as a bespoke offence is made. It continues to constitute an habituated aspect of intimate partner violence, attracts much concern and attention from a

\footnotetext{
${ }^{87}$ Susan S.M. Edwards “The strangulation of female partners” Crim. L.R. 2015, 12, 949-966.

${ }^{88}$ See for example Offences against the Person Act 1861, s.16 threats to kill, recognises, 'A person who without lawful excuse makes to another a threat, intending that that other would fear it would be carried out, to kill that other or a third person shall be guilty of an offence...... Section 2 of the Criminal Damage Act 1971 provides in identical language, 'Firearms Act 1968 s.16A, the requisite mens rea is possession of firearm with intent to cause fear of violence. (See $R$ v Elezaj (Kujtim) [2017] EWCA Crim 1713, convicted of two offences, possession of an imitation firearm with intent to cause fear of unlawful violence (count 1) and affray (count 2).) Criminal Justice and Public Order Act 1994, s.51 (1). "A person commits an offence if (a) 'He does an act which harms, and is intended to harm, another person or, intending to cause another person to fear harm, he threatens to do an act which would harm that other person." The harm and fear caused by harassment and stalking behaviour is recognised in the Protection from Harassment Act 1977 s. 4.

${ }^{89}$ The Protection of Freedoms Act 2012 amended the Protection from Harassment Act 1997 and created two new offences of stalking: (section 2A) which is pursuing a course of conduct which amounts to harassment and which also amounts to stalking, (section 4A) involving fear of violence or serious alarm or distress.

${ }^{90}$ See, for example, $R$ v Pickford-Gordon (Daniel) [2016] EWCA Crim 479.

${ }^{91}$ Public Order Act 1986 s. 6 (1-4).

${ }^{92}$ Serious Crime Act 2015, s. 76 (1) (d).

${ }^{93}$ K. Laird, "Evaluating the Relationship between Section 45 of the Modern Slavery Act 2015 and the Defence of Duress: An Opportunity Missed"? [2016] Crim. L.R 395. V. Bettinson, "Criminalising Coercive Control in Domestic Violence Cases: Should Scotland Follow the Path of England and Wales?" [2016] Crim. L. R. 165-180. Susan S.M.Edwards, "Coercion and compulsion - re-imagining crimes and defences" [2016] Crim. L. R. 876-899.

${ }^{94}$ Fear is also an aggravating factor relevant to culpability considered at the sentencing stage across a range of offences "causing another to fear violence" may provide grounds for a "behaviour order" if considered necessary to protect a person from such conduct (criminal procedure rules 2015 (SI. 2015 No. 1490), pt 31). Where a defendant fears violence is also a mitigating factor when considering sentence length in murder (schedule 21 Criminal Justice Act 2003) and in determination of minimum term in relation to mandatory life sentence s.269 (5). It is also a factor regarding the Protection from Harassment Act 1997, s.5 (2) (b) "restraining orders" in order to prevent conduct which may cause another to fear violence. See Sentencing Guidelines Council guidance https://www.sentencingcouncil.org.uk/wp-content/uploads/IntimidatoryOffences-Guideline_WEB.pdf .See also Intimidatory Offences definitive guideline, since where fear is caused a defendants culpability is higher i.e. Protection from Harassment Act 1997 (s. 2A) (s. 2) (s. 4) (s. 4A),Crime and Disorder Act 1998 (s.32(1)(a)(b)), Criminal Justice and Courts Act 2015 (s. 33), Serious Crime Act 2015 (s.76),Offences Against the Person Act 1861 (s.16).
} 
wide range of professionals in the $\mathrm{UK}^{95}$ and has been made the subject of legislation in other jurisdictions ${ }^{96}$ and is an assault which is intended to cause fear in the victim, and succeeds in this purpose.

\section{The Defences}

Turning to review the framework of defences; fear and similar states have been accorded legal recognition in the construction of mens rea and criminal responsibility explicated either in statute or else as an element of the factual basis of the plea. The starting point is what the defendant says and how $\mathrm{s} / \mathrm{he}$ articulates the experience of immediate fear, fear of future harm or being in fear (subjective test), whilst the law sets down an objective test and external standard requiring fact finders to consider whether it is reasonable given the circumstances ${ }^{97}$ to fear or be in fear and to act in the way s/he did. As with anger, the cognitive and behavioural signs of fear are understood by a set of "background expectancies" $" 98$ which are recognised as outward demonstrations linguistic, physical, ${ }^{99}$ and physiological of the underlying symptomatology, albeit complicated by the fact that a person of courage or robustness may fail the first hurdle of establishing an observer's factual requirement of experiencing fear (see Day ${ }^{100}$ below). ${ }^{101}$ In some cases psychiatric or psychological expert opinion on the impact of fear on cognitive function and behaviour has also been required to bolster both victims and especially victim/defendant's claims. ${ }^{102}$ This medicalisation of the impact of fear in criminal defences has also been driven in part by opinion evidence admissibility requirements. ${ }^{103}$

\section{On Reasonableness and Fear}

The law is concerned with whether it is reasonable to experience the emotion of fear as a response to a certain set of circumstances and to act in the way the defendant did. In general terms reasonableness in law instantiates certain predefined experiences and responses as objectively reasonable and understandable, laying claim to universal validity. ${ }^{104}$ In crafting reasonableness particular circumstances and social situations have been deemed more or less comprehendible in instituting fear. The circumstances commonly understood as likely causing a state of fear include, typified scenarios of fear for example, of an intruder in the home, or of imminent attack by an armed or an angry man, or of being raped in the street at night. Yet, fear of being abused by a domestic abuser (experienced largely by women) is not always understood, considered reasonable or within common sense knowledge, and is often contested as insufficient to excuse violent defensive conduct.

\section{Of Proof and Fear}

\footnotetext{
${ }^{95}$ See St Mary's Centre Manchester $16^{\text {th }}$ Annual Conference 2018, "Rape: Not as isolated issue: Sexual Violence and Multiple types of abuse" $25^{\text {th }}-26^{\text {th }}$ April, especially the work of Dr Catherine White, Sara Wallwork Greater Manchester Police and Jo Cunliffe CPS.

${ }^{96}$ Susan S.M.Edwards “The strangulation of female partners” Crim. L.R. [2015] 949-966.

${ }^{97}$ M. Moran, Rethinking the Reasonable Person (Oxford OUP, 2003).

98 H. Garfinkel, "Background Expectancies" in M. Douglas Rules and Meanings (Harmondsworth, Penguin, 1967).

${ }^{99}$ There is also a need to explore automatism i.e. the reaction to bees versus reaction to an armed man. See Law Commission Discussion Paper, Criminal Liability: Insanity and Automatism (Law Com. TSO, 2013).

${ }^{100} R$ v Day [2015] EWCA Crim 1646.

${ }^{101}$ See for a discussion of the Stoics in P. Fisher The Vehement Passions (Princeton, 2003). Where a battered women does not fit the stereotype the plea fails. See M. Dowd, "Dispelling the Myths About the 'Battered Woman s Defense': Towards a New Understanding” (1992) Fordham Urban Law Journal, Vol. 19, No. 3, p. 567. See https://ir.lawnet.fordham.edu/cgi/viewcontent.cgi?article=1550\&context=ulj

102 See R. Ho, and M. Venus, "Domestic Violence and Spousal Homicide: The Admissibility of Expert Witness Testimony in Trials of Battered Women who Kill Their Abusive Spouses" 19951 Jo. Of Fam Studies 24. In $R v$ C (G A) [2013] EWCA Crim 1472, the Court of Appeal recognised that fear and BWS may be of relevance to a defence of duress though not satisfied in the instant case. See also J. Loveless, "Domestic Violence, Coercion and Duress" [2010] Crim. L.R. pp.93-108. ${ }^{103}$ See $R v$ Turner [1975] 1 All ER 70. See also the Daubert standard, Daubert v. Merrell Dow Pharmaceuticals, 509 U.S. 579 (1993).

${ }^{104}$ See N. Lacey, Unspeakable Subjects, (Oxford, 1998); R. S. Duff, L. Farmer, S.E.Marshall, M. Renzo, V. Tadros, The Structures of the Criminal Law (Oxford, 2013); M. Moran, Rethinking the Reasonable Person (Oxford OUP, 2003).
} 
A further problem lies in the fact that fear can cause divers behavioural responses making proof that fear of physical harm or other harms has caused him or her to act in a particular way problematic and contestable. For example, fear reduces the capacity for rationality and impairs reasoning where the individual has "serious difficulty in thinking straight about behaviour." 105 Fear can, as Burke noted, "...rob the mind of all power of acting and reasoning." ${ }^{106}$ Or as Holton and Shute note, "...states like stress and anxiety can destroy self-control." 107 Distinguishable from responses to "immediate fear", fear of a future event can shape perception and cognitive function, creating heightened anxiety, expectation and assessment of risk. Weiss notes, "Fear sears the expectations of many, often making them suffer in anticipation ..." 108 Anticipation also holds fear of violence in the continuous present. Notably, for the abused woman she is in a state of anticipation of future violence which is typical of her fear whilst not typical of what men come to fear. Anticipatory fear is less understood and open to legal challenges of unreasonableness and prosecution rebuttal.

\section{Constructing a defence of fear}

Fear is relevant to a defence of duress, self-defence, householder defence, omission, and fearmanslaughter, where an understanding of immediate fear and fear of future harm can form part of the defence and/or factual basis of the plea and/or function in mitigation of sentence. At one moment fear is recognised as neutralising reason, whilst in another the person in fear is required to stand firm (duress and complicity defences) and in another a person in fear may be unable to assess the situation with measure.

\section{(1)(a) Duress - a well-grounded fear}

Duress, can be pleaded in any criminal offence excluding murder or attempted murder provided the defendant fears immediate "death or serious injury." The defendant must be a person of reasonable firmness whose will is overborne. ${ }^{109}$ The House of Lords in Hasan, ${ }^{110}$ in reviewing the law, reiterated Lord Simon's formulation in Lynch v DPP for Northern Ireland, ${ }^{111}$ who said "I take it for present purposes to denote such [well-grounded] fear, produced by threats, of death or grievous bodily harm [or unjustified imprisonment] if a certain act is not done ... It is arguable that the test should be purely subjective, and that it is contrary to principle to require the fear to be a reasonable one." 112 The case of Hudson and Taylor, ${ }^{113}$ where two defendants were convicted of perjury for lying on oath in respect of witnessing a fight (subsequently overturned on appeal) demonstrates the understanding by the Court of Appeal of the fear experienced by two female witnesses to a violent crime whose fear of future harm was held in present contemplation. The matter, said the court, was one that should have been left to the jury. Widgery L.J. recognised that threats made to the two women from a person in the public gallery although could not be carried out immediately were no less compelling on the minds of those for whom they were intended since they could be carried out in the "streets of Salford that night." Recent case law however has taken a more restrictive approach. ${ }^{114}$ The court in Hasan further underscored the limits of

\footnotetext{
105 Citing S.J. Morse "Diminished Rationality, Diminished Responsibility" 20031 Ohio State Journal of Criminal Law 289. B.J. Mitchell, R.D Mackay and W.J. Brookbanks, (2008) "Pleading for provoked killers: In defence of Morgan Smith" Law Quarterly Review, volume 124: 675-705, 680.

${ }^{106}$ E. Burke, A Philosophical Enquiry into the origin or our ideas of the sublime and the beautiful Part 11 section 11 p. 80. http://0-web.b.ebscohost.com.catalogue.libraries.london.ac.uk/ehost/pdfviewer/pdfviewer?vid=15\&sid=4d51fa0c-f73749bb-81d6-5e97f7b498ee\%40sessionmgr p.104.

107 R. Holton and S. Shute, "Self-Control in the Modern Provocation Defence" (2007) Oxford Journal of Legal Studies 57.

${ }^{108}$ P. Weiss, Emphatics (Vanderbilt University Press, 2000) 214.

${ }^{109} R v$ Dao, Mai and Nguyen [2012] EWCA Crim 1717, where threat of false imprisonment was not sufficient.

${ }^{110} R v$ Hasan [2005] 4 All ER 685.

${ }^{111}$ Lynch $v$ DPP for Northern Ireland [1975] A.C. 653. See $R v$ Hasan [2005] 4 All ER 685.

${ }^{112}$ Lynch $v$ DPP for Northern Ireland [1975] A.C. 686. The law of duress was further clarified in $R v$ Brandford [2016]

EWCA Crim 1794. See also J. Horder, "Occupying the moral high ground? The Law Commission on duress" [1994] Crim. L.R. 334.

${ }^{113} R v$ Hudson and Taylor [1971] 2 W.L.R. 1047.

${ }^{114}$ K. Laird "Evaluating the relationship between section 45 of the Modern Slavery Act 2015 and the defence of duress: an opportunity missed?” [2016] Crim L.R. 395-404.
} 
the defence and its non-applicability for those who voluntary associated with a duressor. Whilst the ultimate object was directed at deterring gang associates, many gang associates may be trapped within the gang to which they joined albeit once in a voluntary capacity. Certainly many abused wives are trapped involuntarily by their abusers. It is difficult to avoid the claim that the law is gendered as an abused wife living (voluntarily/involuntarily) with an abusive husband is excluded. Indeed in Hasan, ${ }^{115}$ Baroness Hale raised her concerns for battered women who experienced duress:

"The battered wife knows that she is exposing herself to a risk of unlawful violence if she stays, but she may have no reason to believe that her husband will eventually use her broken will to force her to commit crimes. ... The battered wife knows very well that she may be compelled to cook the dinner, wash the dishes, iron the shirts and submit to sexual intercourse. That should not deprive her of the defence of duress if she is obliged by the same threats to herself or her children to commit perjury or shoplift for food." 116

The welcome expansion in Coat $^{117}$ (a drugs importation case) upon a referral from the CCRC following submission of fresh evidence of battered woman syndrome, holds out the defence only where the effects of domestic abuse (battered woman syndrome (BWS)) exist in a "serious form." The court did not consider this pertained in the instant case). ${ }^{118}$ Recognition of duress experienced by the abused woman has in effect been largely confined to sentencing, and even here remains insufficiently understood. For example in Simpson, ${ }^{119}$ where a child died as a result of neglect and cruelty the Court of Appeal whilst conceding battered woman syndrome and reducing the sentence, considered it unreasonable and "barely credible" adding that they were "puzzled" that a mother could stand by when such injuries were inflicted. Similarly, in Emery, ${ }^{120}$ where a mother was convicted with her partner of cruelty to a child under sixteen who died as a result of injuries sustained, her duress and her fear of her violent partner was met with scepticism (albeit her sentence was reduced on appeal). The limitations in the defence of duress in recognising only situations of grave violence in threats of death or serious harm, and where the doctrine of reasonableness expects the duressed person including the battered woman, unless suffering from battered woman syndrome in a severe form, ${ }^{121}$ to resist, are of course important to avert floodgate claims. However, the conclusion is nevertheless self-evident and duress remains largely inaccessible to abused women.

The position regarding "duress like defences" sits in disarray across the criminal law. The lower standard required of the defence of "marital coercion" once open to married women acting under the influence or in the presence of the husband has been abolished ${ }^{122}$ on the basis that it was outmoded and out of touch with modern times. The very idea that a woman could come under the control or influence of a husband was argued a reality confined to the nineteenth century and earlier when the wife was femme covert. In addition, it was said that to retain such a defence would unfairly privilege the married woman over the unmarried. Such an abolition ignored the UK's changing cultural demographic according little recognition to the social reality inter alia that women from diverse cultures find themselves under men's dominion. It may also be worth considering the complexity in Brandford, ${ }^{123}$ since the remarks of the Court of Appeal are instructive in demonstrating a heightened understanding of an intimate partner's subornation whatever the cause. Here, whilst upholding the trial judge's decision, but not his reasoning, to withdraw a defence of duress from a woman who had become

\footnotetext{
${ }^{115} R v$ Hasan [2005] 4 All ER 685.

${ }^{116} R v$ Hasan [2005] 4 All ER 685. Para 77.

${ }^{117} R v C(G A)$ [2013] EWCA Crim 1472.

${ }^{118} R v C(G A)$ Ibid. K. Laird also recognises its limitation see Karl Laird "Evaluating the relationship between section 45 of the Modern Slavery Act 2015 and the defence of duress: an opportunity missed?" [2016] Crim L.R. 395-404.

119 (1990-91) 12 Cr. App. R. (S.) 431.

120 R. v Emery (Sally Lorraine) (1993) 14 Cr. App. R. (S.) 394.

${ }^{121} R v C$ GA [2013] EWCA Crim 1472.

${ }^{122}$ Anti-Social Behaviour, Crime and Policing Act 2014, s 177 abolishes the provision under Criminal Justice Act 1925 s.47. Note however HC Deb 20 November 1925 Vol 188 Cc 868-82 where Mr. Greaves-Lord well understood her predicament and begged to leave out the clause at the bill stage.

${ }^{123} R v$ Brandford and others [2017] 4 W.L.R. 17.
} 
involved with her partner in a class A supply drugs case the court held that pressure emanating from several influences and factors including love of a partner and duress arising from fear ${ }^{124}$ were not necessarily irreconcilable. Nonetheless, the understanding of the role of "fear" in these defences continues to rely on male standards of requiring a high standard of physical duress - in threats of physical harm or death and personal fortitude twinned with prescribed circumstances which fails to contemplate the position women and especially abused and coerced women find themselves in.

\section{(1)(b)Compulsion and fear}

However, an expansion in the framework of duress like defences led by public policy and international concern is evident with regard to those who placed in circumstances of human trafficking find themselves compelled to commit criminal offences. The new offence of "compulsion" 125 , derived from the doctrine of necessity, introduced by the Modern Slavery Act (MSA) 2015 s. 45, is applicable to specified offences committed in the context of (s.1 slavery, servitude and forced or compulsory labour or s.2 human trafficking). ${ }^{126} \mathrm{~A}$ much lower level of duress is required, hence the term "compulsion", used to differentiate this from duress. Compulsion is extremely broadly construed recognising "force", "pressure", "coercion" and "being obliged" 127 (s.45 (1) (b)), placing a victim of trafficking or enslavement in a unique position within the law where circumstances of all the above including fear ${ }^{128}$ are recognised, where it can be shown that such a person may have "no realistic alternative" but to do the act (s. 45 (1) d). ${ }^{129}$ Recognition of fear, "force", "pressure", "coercion" and "being obliged" under such circumstances prompted Article 8 of Directive 2011/36/EU ${ }^{130}$ which established a nonprosecution entitlement set out in Article 26 of the Council of Europe Convention on Action against Trafficking in Human Beings 2005 acknowledging that circumstances of trafficking may only come to light either at trial or appellate stage. ${ }^{131}$ However, the defendant/victim must satisfy the reasonableness test and here again this mirrors the overarching duress requirement, where for example in $L M, M B, D G$, $B T, Y T v$ The Queen [2010], ${ }^{132}$ articulation of requisite proof of "compulsion" was mapped against the fortitude requirement and the need to demonstrate that the will is overborne. Again the overarching standard is formulated on a male model of what men are considered able and capable of resisting couched in a notion of the resilience of "human will".

\section{(2)Omission and fear}

\footnotetext{
${ }^{124} R v$ Brandford and others [2017] 4 W.L.R. 17. "We regard it as fanciful that Brandford was compelled by fear to carry the drugs on the 27 August. In our judgment, the jury would have been bound to find the defence disproved on grounds both of want of immediacy and voluntary association. That Brandford may very likely have acted out of love, infatuation or under pressure from Alford does not avail her as the circumstances fell well short of the exacting requirements of the defence of duress. ........ That said, they are not necessarily irreconcilable and, in some circumstances, may operate in a cumulative manner. Consider, for example, a credible threat of death to a husband, conveyed also and directly to the wife. The husband then exploits his relationship with his wife to overcome her resistance to committing with him a serious crime to avoid the threat being carried out. Obviously questions remain as to whether the wife comes within the two limbs of Lord Lane CJ's test for duress (set out at para 31 above). But the relationship between pressure and the fear founding duress are not, as it seems to us, necessarily irreconcilable. They are, however, very different."

${ }^{125}$ Examples of psychological coercion which compel a person to commit a criminal offence include blackmail, ... witchcraft or ritual oaths ..., forcing someone to pay an excessive amount of money for substandard accommodation, making significant deductions from an individual's salary, threats of rejection from, or disapproval by, a peer group, family. ${ }^{126}$ Modern Slavery Act 2015 s.45 (7). The defence is limited expressly excluding offences listed in Sch.4 of the Act. ${ }^{127} R v$ Anthony Harrison (2012) EWCA Crim 225, [2013] EWCA Crim 744. See also Susan.S.M. Edwards "Coercion and Compulsion-Re-Imagining Crimes and Defence's" [2016] Crim. L. R. p. 898. See also H.L.A Hart "Compulsion, Coercion and Criminal Responsibility" (1951) 14 M.L.R. 297.

${ }^{128} R v N ; R v E$ [2012] EWCA Crim 189, [2012] 3 W.L.R. 1159. $R v$ LM and Others [2010] EWCA Crim. 2327

${ }^{129}$ Lord Bates', amendment removed this test where child victims of trafficking were concerned. See $23^{\text {rd }}$ February $2015 \mathrm{col}$ 1522 Modern Slavery Bill. http://www.publications.parliament.uk/pa/ld201415/ldhansrd/text/150223-0001.htm

${ }^{130}$ Directive 2011/36/EU/of the European Parliament and of Council of 5 April 2011 on preventing and combating trafficking in human beings and protecting its victims, an replacing Council Framework decision 2002/629/JHA. ${ }^{131} O$ [2008] EWCA Crim 2835.

${ }^{132} L M, M B, D G, B T, Y T v$ The Queen [2010] EWCA Crim 2327, [2011] 1 Cr. App. Rep. 135.
} 
Whether a person's fear inhibits their ability to act and specifically to protect, is a question that has been considered in the context of sentencing regarding the offence of "causing or allowing the death of a child or vulnerable adult" (Domestic Violence and Crime Victims Act 2004, DVCVA, ss. 5 and 6). Whilst there is no defence to the offence of familial homicide ${ }^{133}$ the Home Office Circular ${ }^{134}$ recognises: “... the defendant may have been too frightened to take some of the steps which in other circumstances might have been available to them...there may be limited steps which they could reasonably have taken in order to protect themselves, and even more limited steps which it would be reasonable for them to take to protect the child or vulnerable person who was at risk from violence...". ${ }^{135}$ However, the Circular also states: "The fact that the defendant may be young..., feel intimidated or have suffered violence, will not in itself be conclusive evidence that it was reasonable for the defendant not to take any steps to protect the victim." This provision has been much criticised by those working with domestic violence victims precisely because of the failure to adequately address and take into consideration the position of the abused woman. Consider for example Regis, ${ }^{136}$ where the male partner McGregor killed the child (who was pronounced dead following peritonitis and a duodenal rupture caused by blunt force trauma to the abdomen). The female partner was convicted under DVCVA. The appellant claimed she was under McGregor's control and unable to act. On appeal, a sentence of three years and four months imprisonment was reduced to two years and four months. The judge expressly took account of the psychiatric report, her growing isolation within a controlling relationship, the fact that she was also a victim of McGregor and that she could not end her association with him, ${ }^{137}$ and to this extent as an abused woman her fear causing an inability to act was taken into account.

\section{(3)(a) Self-defence and fear}

In self-defence pleas, the resort to self-defensive reaction can be explained by the accused as a necessary and justified reactive response to a dangerous situation which s/he fears. The Criminal Law Act (CLA) 1967 s.3 (1) provides, "A person may use such force as is reasonable in the circumstances in the prevention of crime, or in effecting or assisting in the lawful arrest of offenders or suspected offenders or of persons unlawfully at large." It is for the prosecution to disprove. Section 76(1) (b) Criminal Justice and Immigration Act (CJIA) $2008^{138}$ establishes a standard of "reasonable force" and s. 76 (6) provides, "... [In a case other than a householder case], the degree of force used by D is not to be regarded as having been reasonable in the circumstances as D believed them to be if it was disproportionate in those circumstances". Self-defence relies then on the doctrine of proportionality, on the defendant's "honest" and (interestingly) "instinctive" assessment of the circumstances (s. 76(3)).The accused, in self-defence might of course be in a state of indignation or motivated by altruism but also might be in a state of fear which we have already established can impact on the reasonableness of his/her reaction.

\section{(3)(b)A tale of two Householders}

\footnotetext{
${ }^{133}$ S. Morrison, "Should there be a domestic violence defence to the offence of familial homicide?" [2013] Crim.L.R. 10, 826-838, see also S. Edwards, "More Protection for Victims of Domestic Violence? (The Domestic Violence, Crime and Victims Act 2004)" Denning Law Journal 2005 pp 243-260. See also A. Ashworth, “A new generation of Omissions Offences?" [2018] Crim. L.R. p. 354 at 358.

${ }^{134}$ Home Office Circular 9/2005 "The Domestic Violence and Victims Act 2004: The new Offence of causing the death of a child or vulnerable adult", 04/03/2005, Home Office. https://www.gov.uk/government/publications/the-domestic-violencecrime-and-victims-act-2004.

${ }^{135}$ It is important that prosecuting authorities and the courts recognise that in cases where children are abused female partners who may be unable to take "reasonable steps" or else to recognise the risks to the child because of their own fear and inability to act. See for example, The People \&C., Respondent, v. Joel Steinberg, A/K/A Joel Barnet Steinberg, Appellant 79 N.Y.2d 673; 595 N.E.2d 845; 584 N.Y.S.2d 770 (1992). June 11, 1992. $R$ v Emery and Hedman (1972) (Unreported) 3 November 1992.

${ }^{136} R$ v Regis (Sindyann) [2017] EWCA Crim 2017. See also R v Baker (Rosalin) [2017] EWCA Crim 1686; [2018] 1 Cr. App. R. (S.) 22).

${ }^{137} R v$ Regis (Sindyann) [2017] EWCA Crim 2017, paras 12, 18.

${ }^{138}$ Inserted by s. 43 of the Crime and Courts Act 2013, and s. 148 of the Legal Aid, Sentencing and Punishment of Offenders Act 2012 .
} 


\section{In defence of his home}

Where the circumstances provoking a self-defensive reaction involve an intruder in the home (s.76 (5A)) a different standard applies. "In a householder case, the degree of force used by D is not to be regarded as having been reasonable in the circumstances as D believed them to be if it was grossly disproportionate in those circumstances." Following the original conviction of Tony Martin ${ }^{139}$ public opinion galvanised change to the existing law holding as reasonable under certain circumstances the use of "disproportionate force" without incurring penalty. Aggravated burglary and not mere intrusion by a stranger in the home lies in the imagination of the provision conjuring up images of danger in knives or guns and male physical harm. ${ }^{140}$ Significantly (unlike the reasonableness and fortitude required of duress and compulsion) in both self-defence and the householder defence, the law reflects the view that a person might not be able to "weigh to a legal nicety" the "amount of necessary action" required (s.76 (7A)). ${ }^{141}$ This sentiment is also found in the latest specimen direction, ${ }^{142}$ and the case of Collins $^{143}$ reiterates the position. (Although we do not encounter such a concession to the abused woman in fear either in duress or in loss of self-control manslaughter to "weigh to a legal nicety" her defensive reaction to a man's violence (discussed below)). A further conundrum arising in both selfdefence and the householder defence is the twinning of the requirement of "honest" with "instinct." Borrowed from Lord Morris in Palmer (Sigismund) v Queen ${ }^{144}$ and placed on a statutory footing, s.76 (7) (b) elides reasonableness with an amalgam of honesty and instinct. Lord Morris asserted:

"If the jury thought that in a moment of unexpected anguish a person attacked had only done what he honestly and instinctively thought necessary that would be the most potent evidence that only reasonable defensive action had been taken. ... The defence of self-defence either succeeds so as to result in an acquittal or it is disproved, in which case as a defence it is rejected." 145

The concession to "instinct" was used to good effect by defence counsel when householder Errol Hanson ${ }^{146}$ killed an intruder, who having entered the house and then was ejected by $\mathrm{D}$ from the premises was stabbed fifty times by him. The prosecution submitted that Hanson's actions were not reasonable, the jury however acquitted. The Judicial College 2018 offers some assistance on this honest /instinctive amalgam and draws on the angered response terminology in the "heat of the moment," embedded in provocation's vocabulary. "It may be necessary to add further directions since in the heat of the moment D cannot be expected to work out exactly how much force to use; and/or that if D used or may have used no more force than he genuinely believed was necessary that would be strong evidence that the force used was reasonable." ${ }^{147}$ The law is certainly not an advocate of instinct as instinct is the opposite of ratiocination, nevertheless the concession to instinctive reaction is accommodated here and also

\footnotetext{
${ }^{139} R v$ Martin [2001] EWCA Crim 2245.

${ }^{140}$ See $R v$ Adams (Kacey Paul) [2017] EWCA Crim 1353. The appellants tortured a retired couple who were tied up, punched, threatened with knives, and suffered severe burns when boiling kettles of water were poured over them. In $R v$ Ward (Marley) [2016] EWCA Crim 1843, a group of some six males or so entered a wearing scarves and hoods brandishing metal bars, and a butcher's knife. See statistics for Domestic burglary in a dwelling, Table Two: https://www.ons.gov.uk/peoplepopulationandcommunity/crimeandjustice/bulletins/crimeinenglandandwales/yearendingsept 2016 Statistical Bulletin: Crime in England and Wales year ending September 2016.

${ }^{141}$ Palmer $v$ R [1971] A.C. 814. The court in R. v Ray (Stephen Jason) [2017] EWCA Crim 1391, emphasised that this does not mean that a householder who uses less than 'grossly' disproportionate force can automatically be guaranteed an acquittal. Ray had argued that if the force used was not 'grossly disproportionate' it must be deemed reasonable. See S. Dickson, Case Comment "Householder self-defence and the erroneous belief: what has changed?" Journal of Criminal Law 2018. K. Laird, "Self-defence: R. v Ray (Stephen Jason) [2018] Crim. L.R, 342-344. M. Dsouza, Case Comment "Understanding The 'Householder Defence': Proportionality And Reasonableness In Defensive Force" Cambridge Law Journal Vol. 75, Iss. 22016 pp.192-196.

${ }_{142}$ Crown Court Compendium Part 1 Jury and Trial Management Summing Up, June 2018 para 2, p.18-1.; para 16, p. 18-4.

${ }^{143}$ See $R$ (on the application of Collins) v Secretary of State for Justice [2016] 3 All ER 490.

${ }^{144}$ Palmer $v$ R [1971] A.C. 814.

145 Palmer $v$ R [1971] A.C. 814 at 831-832.

146 December 20 2017, The Times.

147 See Crown Court Compendium Pt 1 Jury and Trial Management and Summing Up (2018 June) p. 18-3 para 15; p. 18-4 para 24. See also reference at p. 18.7 where Example 4 line 5 to relevance of language, surprise and panic i.e. "uses language or taken by surprise and panicked fearing for his own safety and that of his family."
} 
remains embedded in "loss of self-control manslaughter" (CandJA s. 54) retaining an essentialist understanding of a reflexive and instinctive reaction permitted of the emotion of anger. ${ }^{148}$

The law then seems to propose in self-defence and the householder defence, that it is not only anger but also fear that can erupt in a reflexive or instinctive moment. So whilst in this instance the term "fear" finds no specific mention in statute it plays a significant role in setting out the factual basis for the householder defence where reacting immediately in defence of oneself or of other person(s) is recognised in part as a fear response. The emotion of fear is recognised in CPS guidance ${ }^{149}$ and Home Office briefing documents ${ }^{150}$ where it is stated: "As a general rule, the more extreme the circumstances and the fear felt, the more force you can lawfully use in self-defence." ${ }^{151}$ References to fear are also found in the mainstay of pleadings. Understandably the several components of this defence have proved elusive for the jury and together with the public climate of moral indignation following Martin (and further reflected in the Osborn-Brooks case ${ }^{152}$ ) the CPS have acted as gatekeepers in decisions to prosecute. ${ }^{153}$ In these defences it does appear to be the case that it is men's experience and their contemplation of fear that informs what is considered relevant.

\section{In Her house - an overreaction?}

What is the position when considering the legal position of women who when in their home defend themselves from the male domestic abuser who may be legally occupying a shared home or otherwise be an intruder? In the latter case where a former boyfriend intrudes and coerces his way into her home and is killed by her (as she fears his violence) in law's contemplation he is not considered the archetypal intruder, nor her the archetypal householder. But she might have every reason to fear him such that a householder defence with its concessions to instinct, disproportionality and a malleable reasonableness should be open to her not only within a householder defence but significantly within a defence of fear of "serious violence" under s. 55(3) CandJA committed in her home. Considering homicide in England and Wales, of female victims, 77\%, (144) for year ending March 2017 were killed in this location, this compares with $38 \%$ of male homicides (199). ${ }^{154}$ With regard to intimate partner killings ${ }^{155}$ this percentage is even higher providing evidence of the danger of the home, which surely must be relevant. $R v$ Day, ${ }^{156}$ is of some relevance to this point and suggests a more enlightened expansion of the householder defence. D (a female occupant) was convicted of common assault on V (a male). D (in lawful occupation) asked $\mathrm{V}$ to leave, when $\mathrm{V}$ did not, $\mathrm{D}$ pushed $\mathrm{V}$ out of the door and $\mathrm{V}$ fell backwards hitting his head. The trial judge declined to leave the householder defence to the jury. But since D was a guest in the house and therefore not a trespasser or intruder and in lawful occupation D appealed contending that the householder defence should have been open to her and put to the jury. The Crowns case was that the applicant had used unreasonable force when she pushed Jones adding that nowhere in her interview had she indicated that she feared for her safety when she pushed him. (Perhaps it is worth noting that defendant's linguistic accounts, excuses and justifications develop in tandem with legal

\footnotetext{
${ }^{148}$ See Law Commission Discussion Paper, Criminal Liability: Insanity and Automatism, (Law Com. TSO, 2013). Law Commission Consultation Paper, Partial Defences to Murder No 173 (Law Com. TSO, 2003) para 3.38 queries why anger affords a ground for mitigating violent conduct.

${ }^{149}$ CPS guidance on householder defence. https://www.cps.gov.uk/legal-guidance/self-defence-and-prevention-crime

${ }^{150}$ See S. Lipscombe, Householders and the criminal law of self-defence Standard Note: SN/HA/2959 Last updated: 10 January 2013 Home Affairs. p.6.

${ }^{151}$ See S. Lipscombe, Householders and the criminal law of self-defence Standard Note: SN/HA/2959 Last updated: 10 January 2013 Home Affairs. p.3.

152 The CPS have taken the decision not to bring any charges against Richard Osborn-Brooks who killed an intruder in his home April 2018. See https://uk.news.yahoo.com/police-fear-increased-tension-over-113740159.html

${ }^{153}$ Between 1990 and 2005 there were only 11 prosecutions of people who had used force against intruders into houses, commercial premises or private land. Only seven of those appeared to have resulted from domestic burglaries. See S.

Lipscombe, Householders and the criminal law of self-defence Standard Note: SN/HA/2959 Last updated: 10 January 2013 Home Affairs p.6.

${ }^{154}$ Homicide in England and Wales :year ending March 2017 ONS

https://www.ons.gov.uk/peoplepopulationandcommunity/crimeandjustice/articles/homicideinenglandandwales/yearendingm $\operatorname{arch} 2017$

${ }^{155}$ E. Bridger, H. Strang, J. Parkinson, L. W. Sherman "Intimate Partner Homicide in England and Wales 2011-2013:

Pathways to Prediction from Multi-agency Domestic Homicide Reviews"Cambridge Journal of Evidence-Based

Policing September 2017, Volume 1, Issue 2-3, pp. 93-104.

${ }^{156} R v$ Day [2015] EWCA Crim 1646.
} 
relevance and the defendant might not have considered her fear, if indeed she was in fear, would have been material and therefore for that reason failed to mention it). The Court of Appeal quashed the conviction holding that the householder defence was indeed open to her. But who is the reasonable person of the household and when is such self-defensive reaction reasonable? Does it derive from an understanding of an abused woman or person in fear of an abuser who coerces his way into the house from which retreat and escape is often impossible?

\section{(4) Manslaughter, Gender and Fear}

It is in the CandJA s.55 (3) where is found the most explicit recognition in statute of the impact of fear on mens rea, where fear can cause a person to lose self-control and kill another. ${ }^{157}$ Section 55(3) "fear of serious violence" is the product of a long struggle within Anglo-American jurisprudence challenging the defence to murder (manslaughter-provocation) in particular, contesting it's privileging of the emotion of men's anger and eschewing the emotion of women's fear.

Significantly, respondents to the Law Commission's Consultation Paper Partial Defences to Murder $^{158}$ were of the view with regard to developing an abused woman's defence that "extreme emotional disturbance" was preferable to a test based on loss of self-control. ${ }^{159}$ One of the enduring problems lies in the retention of the loss of self-control requirement where fear is the trigger. The concept of loss of self-control remains relatively intact and problematic with many of its original trappings, notwithstanding the fact that CandJA abolishes provocation and that judicial guidance asserts that loss of self-control within the CandJA is different to the loss of control in provocation that preceded it. ${ }^{160}$ So in CandJA s.55(3) despite some gains for abused women, the alchemy persists and whilst certainly holding the abused woman within its contemplation for a moment, she who kills out of fear, with all its despair, hopelessness, sorrow, helplessness, anguish and trauma, is still required to "lose self-control" (s. 54). And perhaps there is a loss of control in desperation. But the legal template of loss of self-control s.55(4) (a)(b) remains soldered to a male angered reaction with its outward demonstration embedded in a legacy of "serious wrongs" and "justifiable" hubris.

It is worth noting that under the old law of provocation fear was expressly excluded from loss of selfcontrol. Justice Devlin in Duffy said: "Severe nervous exasperation or a long course of conduct causing suffering and anxiety are not by themselves sufficient to constitute provocation in law." ${ }^{161}$ Lord Steyn in reviewing which particular emotions were required to satisfy a claim to provocation said: "A loss of self-control caused by fear, panic, sheer bad temper or circumstances (e.g. slowdown of traffic due to snow) would not be enough." ${ }^{162}$ However, in 2006, the Law Commission ${ }^{163}$ recommended that unlawful homicide that would otherwise be first degree murder should instead be second degree murder if there was "fear of serious violence" towards the defendant or another. ${ }^{164}$ One consultee wanted to widen the

\footnotetext{
${ }^{157}$ See for example Longsworth v R [2015] 3 LRC 580, 607. Longsworth appealed against conviction and sentence. Fresh evidence was admitted which established that, at the time of the incident, she was suffering from battered woman syndrome (BWS), a subcategory of Post-Traumatic Stress Disorder (PTSD) a severe psychiatric condition as she had been in abusive relationships for most of her life, including her relationship with the deceased, which could establish a defence of diminished responsibility.

${ }^{158}$ Law Commission Consultation Paper, Partial Defences to Murder No 173(Law Com. TSO, 2003).

${ }^{159}$ Law Commission Report, Partial Defences to Murder Report No 290(Law Com. TSO, 2004) at para 3.49, p.41.

${ }^{160}$ Crown Court Compendium Part 1 Jury and Trial Management Summing Up, June 2018 para 3, p.19-10.

${ }^{161}$ Duffy [1949]1 All ER 932.

${ }^{162} R v$ Acott [1997] 1 All ER 706.

${ }^{163}$ Law Commission Report Murder, Manslaughter and Infanticide No 304 (Law Com. HC 30, London, TSO, 2006) para 917 (1) (a)(ii) p. 174.

A. Simester and G. Sullivan, Criminal Law Theory and Doctrine (3rd edn, Hart, 2007) 355. 72. See Law Commission Consultation Paper, Partial Defences to Murder No 173 (Law Com. TSO, 2003) paras 4.166-4.167. C. Fairbairn, G. Danby and P. Strickland, "Coroners and Justice Bill: Committee Stage Report" Research Paper 09/27 (2009) 25.

${ }^{164}$ Murder, Manslaughter and Infanticide (Law Com No 304) (HC 30, London, TSO, 2006) para 9-17 (1) (a) (ii) p. 174.
} 
prevailing definition and proposed "fear of serious violence or significant harm towards the defendant." However, significant harm was rejected by the Law Commission as too wide and "blurring the test."165

Certainly it is true that s.55 (3) holds, in part, an abused and fearful woman in its contemplation, as does (s.54 (2)) which relegates a delay in time between the last act of the deceased and the killing to a consideration and not a requisite element of the offence. ${ }^{166}$ Both provisions are founded on an understanding that fear as an emotional state can be experienced immediately upon the threat, or prior to in anticipation of future harm, where it is anticipatory. However, the endeavours leading to s. 55(3) have been incompletely realised since the qualifying threshold for this defence requires a high and arguably male standard in "serious" and in specifying "violence" i.e., "fear of serious violence". The subsection applies if D's loss of self-control is attributable to D's fear of serious violence from V against $\mathrm{D}$ or another identified person. Regrettably, whereas the thinking behind the legislative reform was premised on developing an understanding of cumulative fear i.e., fear in the past shaping fear for the future, this important understanding is compromised, since the "serious violence" requirement contemplates something approximating a proportionate response or at least inhabits a position on the proportionality continuum. Neither men's anger in the old provocation, nor the requirements of CandJA s.54 (loss of self-control) nor the householder defence require this elevated threshold or precise substantiation. The requirement of "serious violence" misses the reality confronting an abused woman setting in place a male standard informed by an equality of arms. In 1977, by the Supreme Court of Washington in Wanrow $^{167}$ recognised that the objective standard "compounds th[e] error by utilizing language suggesting that the respondent's conduct must be measured against that of a reasonable male individual finding himself in the same circumstances." 168 Justice Wilson in $R \mathrm{v}$ Lavellee ${ }^{169}$ perfectly understood this too, "I am skeptical whether the average fact-finder would be capable of appreciating why her subjective fear may have been reasonable in the context of the relationship. After all, the hypothetical "reasonable man" observing only the final incident may have been unlikely to recognise the batterer's threat as potentially lethal." It also eschews any understanding of anticipatory and cumulative fear, recognised as "anticipation syndrome." Justice Kirby in Osland v the Queen ${ }^{170}$ understood this aspect of the "battered woman's reality," as did the court in the New South Wales case of Hickey ${ }^{171}$ where a plea of self-defence succeeded and held "[a] battered woman's reaction to her abuser's violence does not necessarily follow from the severity of the last act of violence, but flows from her perception of the severity of the threat he poses to her life."172

The requirement of fear of "serious violence" restricts the reach of this defence, as women defendants struggle to provide the evidential threshold required, where evidence of coercion, control, or even when being held in a state of fear and subjection simply might not satisfy. One route to leveling the unevaluable might be by pleading the two defences of self-defence and fear /manslaughter together. The authors of the Partial Defences to Murder Report recognised that self-defence is "all or nothing"173 and that it might be strategically important to plead both self-defence and loss of control /fear manslaughter, notwithstanding the obvious conceptual difficulties. ${ }^{174}$ Such an option has also been recognised in recent judicial guidance. ${ }^{175}$ Some ground has been made and the consideration of the abused woman's fear in self-defence is being more ambitiously argued by counsel and conceded by the

\footnotetext{
${ }^{165}$ Law Commission Report, Partial Defences to Murder No 290 (Law Com. TSO, 2004) para 3.102, p. 53.

${ }^{166}$ Coroners and Justice Act 2009, s. 54(2).

${ }^{167}$ The State Of Washington, Appellant, v Yvonne L. Wanrow, Respondent. No. 43949, 88 Wn.2d 221 (1977). 559 P.2d 548.

The Supreme Court of Washington. State v. Kelly, 478 A.2d 364 (1984), at p. 378. See also the Canadian case of The State v Lavallee [1990] 1 SCR 152. See S. Edwards, "Anger and Fear as Justifiable Preludes for Loss of Self-Control” (2010) 74 JCL 223-241, 233.See also Clare Dalton and Elizabeth M. Schneider, Battered Women and the Law (New York, Foundation Press, 2001) ch 10.

${ }^{168}$ The State Of Washington, Appellant, v Yvonne L. Wanrow, Respondent. No. 43949, 88 Wn.2d 221 (1977). 559 P.2d 548. Para 11.

169 [1990] 1 SCR 152.

170 Osland v The Queen (1999) 159 ALR 17 1, para 55.

${ }^{171} R v$ Hickey (1992) 16 Crim LJ 271.

${ }^{172}$ Susan S.M. Edwards, “Anger and Fear as Justifiable Preludes for Loss of Self-Control” (2010) 74 JCL 223-241 233.

${ }^{173}$ Law Commission Report, Partial Defences to Murder No 290 (Law Com. TSO, 2004) para 4.8, p.74, para 4.22, p. 79.

${ }^{174}$ Law Commission Report, Partial Defences to Murder No 290 (Law Com. TSO, 2004)) para 3.97, p. 52.

175 Crown Court Compendium Part 1 Jury and Trial Management Summing Up, June 2018, p.19-10, para 18(5).
} 
court. The case of Elizabeth Hart-Browne ${ }^{176}$ where the fearful abused partner killed her abuser, provides one such example of a successful plea of self-defence to a charge of murder where her fear of her partner's violence was central.

One cannot help but observe that scenarios of danger, of harm or impending harm and of reasonableness, within the defence's framework especially, have been informed by male perceptions of and responses to fear and male notions of reasonableness. Perhaps this is not surprising after all, women's engagement in violent crime, in self-defensive preservation or in killing is so very much less than men's. These very legitimate concerns of an implied masculinism in constructing reasonableness and legal concessions have also drawn comment from the judiciary. On the matter of self-defence, HHJ Ann Goddard QC in response to Partial Defences to Murder Consultation Paper ${ }^{177}$ said: "Such a woman may use a weapon against an unarmed but violent man. I believe that I could properly direct a jury that the use of a weapon in circumstances does not per se rule out self-defence i.e. necessarily make the woman's acts unlawful because the jury have to consider the nature of the threat against the background" 178 (sic). Vera Baird QC also submitted her case for the need to recognise that a woman facing attack from a man was placed in a very different position from a male counterpart when considering imbalance in size, social conditioning, physical and bodily vulnerability. ${ }^{179}$

On the matter of duress, Baroness Hale in Hasan, ${ }^{180}$ also prefaces the need to consider the legal relevance of the context as it impacts on gender:

"I accept that even the person with a knife at her back has a choice whether or not to do as the knifeman says. The question is whether she should have resisted the threat. But, perhaps because I am a reasonable but comparatively weak and fearful grandmother I do not understand why the defendant's beliefs and personal characteristics are not morally relevant to whether she could reasonably have been expected to resist" 181 [And] "It is another thing to deny it to someone who has a quite different reason for becoming associated with the duressor and then finds it difficult to escape. I do not believe that this limitation on the defence is aimed at battered wives at all, or at others in close personal or family relationships with their duressors and their associates, such as their mothers, brothers or children." 182

The threshold of "fear of serious violence" (s. 55(3)) emboldens whose notion of fear then? Not hers at least not completely. After all it fails to fully comprehend women's fear in construing what is reasonable and what particular behaviours are considered lawfully compromising of mens rea and what circumstances are considered reasonable to trigger a fatal response. After all, as stated earlier the battered woman in fear is also (like the male householder) unable to "weigh to a legal nicety" what she must do or action she must take to protect her life. Section 55(3) requires her to fear "serious violence" whilst the male householder presented with an intruder is permitted the use of disproportionate force and therefore does not have to establish a fear of serious violence. The test of reasonableness for selfdefence and the householder defence both allow for the levity of an "instinctive reaction" which is not permitted for the battered woman. Little surprise that these inequities across defences have raised academic concerns. Nicola Wake ${ }^{183}$ writes, "Recent amendments under the Crime and Courts Act (CCA) 2013 have exacerbated the difficulties in this area by placing the 'startled householder' in a better position than every other defendant in cases involving self-defence." 184

\footnotetext{
${ }^{176}$ Elizabeth Hart-Browne, April 27th 2017, is a case in point. She pleaded self-defence and s 54 CJA loss of self-control/ fear (55(3)). She was acquitted. Discussed with counsel.

${ }^{177}$ Law Commission Consultation Paper, Partial Defences to Murder No 173 (Law Com. TSO, 2003).

${ }^{178}$ Law Commission Report, Partial Defences to Murder No 290 (Law Com. TSO, 2004) para 4.12, p.76

${ }^{179}$ Law Commission Report, Partial Defences to Murder No 290 (Law Com. TSO, 2004) para 4.15, p.76-77.

${ }^{180} R v$ Hasan [2005] 4 All ER 685.

${ }^{181} R v$ Hasan [2005] 4 All ER 685, para 73.

${ }^{182} R v$ Hasan [2005] 4 All ER 685, para 78.

${ }^{183}$ N. Wake "Battered women, startled householders and psychological self-defence: Anglo-Australian perspectives" Journal of Criminal Law 2013 pp. 433-457.

${ }^{184}$ N. Wake, "Battered women, startled householders and psychological self-defence: Anglo-Australian perspectives" Journal of Criminal Law 2013 pp. 433-457.
} 
But there are significant further contradictions across the wider legal framework. Whilst "coercion" of an intimate or family member is an offence (s.76 of the SCA 2015) a victim of coercion cannot rely on the fact of being coerced as a defence, the defence of "compulsion" (MSA 2015 S.45) available only to victims of slavery or trafficking. This is stridently anomalous when other legislative efforts have recognised the contemporary reality facing (largely women) in creating the offence of coercion in forced marriage ${ }^{185}$ and the offence of coercion. On February $27^{\text {th }} 2019$ the appeal of Sally Georgina Challen ${ }^{186}$ convicted of the murder of her husband was heard. Counsel adducing the grounds of coercive control, recognized in law as a stand-alone offence since 2015, (see earlier) successfully persuaded the Court of Appeal to quash the murder conviction. ${ }^{187}$ The Court of Appeal not wishing to usurp the function of a jury and in hearing and deciding upon fresh evidence in the light of new changes in the law since the appellant's conviction, ordered a retrial. However it will be now for the prosecution to decide whether to proceed with a charge of murder. They could accept the defence plea to manslaughter on the grounds of diminished responsibility rather than on the basis of fear loss of selfcontrol s.55 (3) CandJA 2009. Fear loss of self-control requires fear of serious violence and this continues to constitute a major hurdle. Whilst coercive conduct is an offence the pivotal question is whether his coercive conduct is sufficient along with other factors to afford a defence to murder given the specific threshold required in the wording of s. 55(3) Cand JA 2009 which requires a defendant to fear 'serious violence.' As Bettinson has noted with regard to coercive conduct "the behaviour can be managed through acts which do not involve violence". ${ }^{188}$ Herring acknowledges that the level of control rather than the level of violence is at the centre of coercive control. ${ }^{189}$ Such a plea at retrial will require careful nuancing such that a plea of diminished responsibility may well be the only route albeit placing responsibility on the defendant and not on the deceased's conduct. As Bettinson points out "It has been argued that this defence is 'inherently unsuitable' in domestic violence cases where the abused kills the abuser as it medicalises the defendant through the use of disorders like BWS and therapeutises domestic violence. This concern extends to coerced and controlled victims, whether there has been the presence of physical harm or otherwise, "victims of coercive control are vulnerable, but not ... mentally unwell'." 190 It is to be noted however that the forensic psychiatrist for the Crown did not consider that the appellant had a mental disorder at the time which is why the Court of Appeal were not themselves able to substitute the murder conviction with diminished responsibility manslaughter. It is also to be noted that the trope of jealous wife constituted a central plank in the Crown's case and may well continue to be argued upon retrial. Jealousy is not incompatible with coercion and fear! nor does jealousy negate coercion and fear. The case of Sarah Thornton is significant a retrial was ordered which went to a full trial where fresh evidence of diminished responsibility (BWS) and provocation (the law at that time) was put forward and the jury on retrial convicted of manslaughter. ${ }^{191}$

This ruling in the Challen case will open up the possibility of appeal for other cases where women have killed coercive and controlling partners.

\footnotetext{
${ }^{185}$ Forced Marriages (Civil Protection) Act 2007, Anti-Social Behaviour, Crime and Policing Act 2014 s. 120 , s.121.

${ }^{186}$ Leave to appeal granted on March $1^{\text {st }} 2018$ in the case of Sally Georgina Challen. https://www.thetimes.co.uk/edition/news/sally-challen-can-appeal-against-conviction-for-killing-husband-

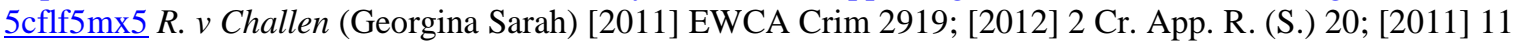
WLUK 692 (CA (Crim Div)); R. v Challen (Georgina) [2018] EWCA Crim 471 (CA (Crim Div))

${ }^{187} \mathrm{~V}$. Bettinson, "Aligning partial defences to murder with the offence of coercive or controlling behaviour" Journal of Criminal Law 2019.
}

${ }^{188}$ DG. Dutton and S Painter, "Emotional Attachments in Abusive Relationships: A Test of Traumatic Bonding Through Theory' (1993) 8 Violence and Victims 105, 107.

${ }^{189} \mathrm{~J}$ Herring, "The Serious Wrong of Domestic Abuse and the Loss of Control Defence' in A Reed and M Bohlander (eds), Loss of Control and Diminished Responsibility Manslaughter: Domestic, Comparative and International Perspectives (Ashgate, Surrey, 2011), 73.

${ }^{190}$ C. Wiener, "What is "Invisible in Plain Sight": Policing Coercive Control' (2017) 56(4) The Howard Journal 500 at 506.

191 Thornton retrial, Oxford Crown Court see Susan Edwards and Charlotte Walsh "The justice of retrial?" 146 NLJ 857m 1996 


\section{Conclusion}

The understanding of fear and analogous states and of reasonableness has largely imposed a male understanding of scenarios of danger, and the legitimation of what kind of circumstances can be lawfully responded to with violence. The law has contrived around particular emotional states giving them credence, recognition and authority and imposing as objective an essentially male standard within the law, where anger and jealousy ${ }^{192}$ still remains privileged, ${ }^{193}$ whilst fear, experienced by abused women especially, somewhat misaligned ${ }^{194}$ requiring or assuming physical violence to trigger it. Whilst defences are assessed in the light of "relevant circumstances" a hierarchy ${ }^{195}$ of circumstances pertains with regard to what is reasonable and relevant. The Law Commission Report Partial Defences to Murder recognised that an angry strong person was treated more favourably than a frightened weak person. ${ }^{196}$ Many commentators have remarked on the way in which what passes as common sense is shaped by the male experience. ${ }^{197}$ Of course the law has abandoned some excuses for anger (infidelity) hitherto acceded as having the potential to lead to homicide, ${ }^{198}$ and the law has accommodated fear as a trigger to loss of self-control but only in part. There is still the need for further consideration with regard to abused women to enable "the trier of fact to give greater weight to the social reality in which the accused operates" 199 echoed by HH Ann Goddard (above) where the nature of the threat, she continues, must be judged against the background. Such reality and background has not been sufficiently aligned in the law to women's fear of male violence within the domestic context or with regard to the defences described above. Since the privileged understandings of reality shape what is commonly accepted then, with fear, as with anger, the male experience of legitimate social scenarios impose on the objective standard. Scenarios of self-defensive conduct are characterised by what men do and how men react to anger and fear or both. Scenarios of loss of self-control and fear require fear of serious violence. With regard to the role of fear across both offences and defences some further rethinking of the ambit of instilling fear in another as a means of causing harm, and the role of fear in causing a person to commit an offence need further consideration.

\footnotetext{
${ }^{192}$ If invoked as a part of her course of conduct see $R v$ Clinton [2012] 1 Cr App R 26, or accommodated within a diminished responsibility defence within CandJA s.52.

${ }^{193}$ D. M. Kahan, and M. C. Nussbaum, "Two Conceptions of Emotion in Criminal Law" (1996) 96 Col. L.R. 269. S. Edwards, "Abolishing provocation and reframing self-defence: the Law Commission's options for reform” [2004] Crim. L. R. 181, 192.

${ }^{194}$ D. M. Kahan, and M. C. Nussbaum, “Two Conceptions of Emotion in Criminal Law” (1996) 96 Col. L.R.

269. Susan S.M. Edwards, “Abolishing provocation and reframing self-defence: the Law Commission's options for reform” [2004] Crim. L. R. 181, 192.

195 See M. Foucault, Archaeology of Knowledge (Routledge Classics, 2002).

${ }^{196}$ Law Commission Report, Partial Defences to Murder No 290) (Law Com. TSO, 2004) para 3.29, p.36.

${ }^{197}$ C. Dalton and E. Schneider, Battered Women and the Law (Federation Press, 2000) 719.

198 Coroners and Justice Act s. 55 (6) c.

${ }^{199}$ M. Moran, Rethinking the Reasonable Person (Oxford OUP, 2003) 206 in referring to D.A. Donovan and S.M. Wildman, "Is the Reasonable Man Obsolete? A Critical Perspective on Self-Defence and Provocation" (1981) 14 Loyola LAL Rev 435.
} 
